\author{
Marta Luber \\ (D) https://orcid.org/0000-0003-0846-6684 \\ Uniwersytet Papieski Jana Pawła II w Krakowie
}

\title{
Relacja $z$ ojcem jako filar kształtowania tożsamości dziecka
}

Tożsamość jest pojęciem definiowanym przez wiele dziedzin nauki, takich jak psychologia, socjologia czy antropologia. Na jej kształt składa się wiele elementów, jakimi są m.in. przekonania, osobowość, wizja własnej osoby czy wartości. Celem tworzenia tożsamości jest przede wszystkim stworzenie własnego, spójnego obrazu

Każde dziecko odczuwa naturalną potrzebę rozwoju. Aby pełny rozwój mógł nastąpić, należy dziecko wychowywać w rodzinie pełnej miłości, zrozumienia i akceptacji ${ }^{2}$. Wynika to nie tylko z obserwacji socjologów, pedagogów czy psychologów, ale także wprost mówi o tym Konwencja o prawach dziecka. W myśl tego dokumentu zarówno matka, jak i ojciec ponoszą pełną odpowiedzialność za wychowanie, a także za rozwój swoich dzieci ${ }^{3}$.

Obecność ojca w procesie kształtowania tożsamości dzieci jest kluczowa. Jego nadrzędnym zadaniem nie jest troska o kapitał ekonomiczny, a dostarczenie potomnym wzorca do naśladowania oraz przekazanie im konkretnych wartości. Na tej podstawie młoda jednostka buduje swój obraz i poczucie wartości oraz kształtuje swoje relacje z rówieśnikami. Więź ojca z dzieckiem wpływa również na postępy w szkole czy później w karierze zawodowej i życiu osobistym ${ }^{4}$. Relacja syna z ojcem jest klu-

\footnotetext{
1 Por. G. Węgrzyn, Tożsamość Ekonomiczna Górnośląaków, Katowice 2017, s. 8-10.

2 Por. E. W. Willemsen, K. K. Waterman, Ego Identity Status and Family Environment: A Correlational Study, „Psychological Reports”, nr 69 (3).

3 Por. Konwencja o prawach dziecka. Dz. U. z 1991 r. nr 120, poz. 526.

4 Por. E.M. Krampe, R.R. Newton, The Father Presence Questionnaire: A New Measure
} 
czowa dla prawidłowego rozwoju chłopca. Wynika to przede wszystkim z faktu, iż syn postrzega ojca jako mężczyznę, z którym chce się utożsamiać w przyszłości. Córka natomiast dzięki obecności ojca w życiu buduje obraz samej siebie jako kobiety świadomej swojej wartości, samodzielnej i pewnej siebie ${ }^{5}$.

Celem artykułu jest przedstawienie pojęcia tożsamości i procesu jej kształtowania, a także ukazanie relacji dziecka z ojcem jako kluczowej na drodze do prawidłowego rozwoju młodego człowieka i kształtowania się jego tożsamości.

\section{Tożsamość}

Na tożsamość każdego człowieka składają się cechy, przekonania, osobowość, wygląd, a także wizja własnej osoby - przy uwzględnieniu niepowtarzalności i odrębności od innych jednostek ${ }^{6}$. Jest ona również ściśle związana ze świadomością, a także z utożsamianiem się z konkretnymi elementami rzeczywistości. Celem każdej jednostki jest stworzenie spójnego obrazu własnej osoby. Niezwykle istotny jest fakt, że tożsamość kształtuje się zarówno w relacji do samego siebie, jak i do innych. Ważnym jej elementem jest świadomość, iż rzeczywiście istnieje coś, co łączy dane indywiduum z pozostałymi jednostkami w zbiorowości ${ }^{7}$.

Jednym z pierwszych psychologów wyraźnie zainteresowanym tematem tożsamości był Erik Erikson (1902-1994). Wyszczególnił on osiem faz rozwoju człowieka, różniących się między sobą jakościowo. Eriksonowska struktura opiera się na rozróżnieniu między psychologicznym poczuciem ciągłości, znanym jako tożsamość ego (czasami identyfikowana po prostu jako „jaźń”), a zbiorem ról społecznych, które dana osoba może odgrywać,

of the Subjective Experience of Being Fathered. Fathering, 4/2, s. 159-190, http://citeseerx. ist.psu.edu/viewdoc/download?doi=10.1.1.839.9976\&rep=rep1\&type=pdf (30.12.2019).

5 Por. R.B. Ginsberg, Parent-Adolescent Relationship Program (PARD): Relationship enhancement therapy with adolescents and their families (fathers and sons), „Psychotherapy”, $\mathrm{nr}$ 35, 1, s. 108-112.

6 Por. P.I. James, Despite the Terrors of Typologies: The Importance of Understanding Categories of Difference and Identity, „Interventions: International Journal of Postcolonial Studies", nr 17 (2), s. 174-195.

7 Por. G. Węgrzyn, Tożsamośćc.., dz. cyt., s. 8-10. 
zwanych tożsamością społeczną lub tożsamością kulturową. Praca Eriksona, zgodnie z tradycją psychodynamiczną, miała na celu zbadanie procesu formowania się tożsamości w ciągu całego życia ${ }^{8}$.

Można wyróżnić kilka rodzajów tożsamości:

1. Tożsamość psychologiczna - odnosi się do obrazu siebie, własnego modelu mentalnego, samooceny i indywidualności. Jest ona definiowana jako całość samokonstruktywności, w której wyraża się ciągłość między tym, jak się konstruowało w przeszłości, a tym, jak konstruuje się obecnie, aby aspirować do bycia w przyszłości ${ }^{9}$. W psychologii poznawczej termin „tożsamość” odnosi się do zdolności do autorefleksji i świadomości siebie ${ }^{10}$.

2. Tożsamość płciowa - stanowi istotną część tożsamości tak w psychologii, jak i socjologii, ponieważ w znacznym stopniu dyktuje sposób postrzegania siebie, zarówno jako samodzielnej jednostki, jak i siebie wobec innych ludzi, pomysłów czy natury.

3. Tożsamość społeczna - związana jest z jednostką, która utożsamia się z pewnymi grupami społecznymi. Można wyróżnić tożsamość narodową, kulturową, etniczną, religijną, ekonomiczną lub historyczną ${ }^{11}$. Inne aspekty tożsamości, np. etniczne czy zawodowe, mogą również być mniej lub bardziej znaczące - lub znaczące w niektórych, konkretnych sytuacjach, ale już nie w innych ${ }^{12}$.

4. Tożsamość zawodowa - to identyfikacja z zawodem, przejawiająca się poprzez zestawienie ról, obowiązków, wartości i standardów etycznych przyjętych przez zawód ${ }^{13}$.

8 Por. P. Weinreich, W. Sanderson, Analysing Identity: Cross-Cultural, Societal and Clinical Contexts, East Sussex 2003, s. 26-34.

9 Por. P. Weinreich, The operationalisation of identity theory in racial and ethnic relations, „Theories of Race and Ethnic Relations. Comparative Ethnic and Race Relations”, s. 299.

10 Por. M. R. Leary, J. PriceTangney, Handbook of self and identity, Nowy Jork 2003, s. 78.

11 Por. G. Węgrzyn, Tożsamość..., dz. cyt., s. 8-10.

12 Por. P. Weinreich, W. Sanderson, Analysing Identity..., dz. cyt., s. 26-34.

13 Por. H.H. Goltz, M. L. Smith, Forming and Developing Your Professional Identity Easy as PI, „Health Promotion Practice”, nr 15 (6), s. 785-789. 


\section{Kształtowanie tożsamości}

Kształtowanie się tożsamości, znane również jako indywiduacja, jest rozwojem odrębnej osobowości jednostki. Tożsamości powstają na wielu poziomach: mikro, mezo, makro oraz globalnie. Poziom mikro to samookreślenie i związek z ludźmi oraz problemy postrzegane z perspektywy osoby. Poziom mezo jest miejscem, w którym nasze dane identyfikacyjne są przeglądane, formowane i przesłuchiwane przez nasze bezpośrednie otoczenie. Poziom makro odnosi się do powiązań między osobami, problemami i grupami z perspektywy krajowej. Poziom globalny natomiast to powiązania między osobami, problemami i grupami z perspektywy światowej ${ }^{14}$.

Tożsamość jest często opisywana jako skończona i składająca się z oddzielnych części (rodzinnej, kulturowej, osobistej, zawodowej itd.), ale według Parkera J. Palmera jest to ciągle ewoluujący rdzeń w obrębie naszej genetyki (biologii), kultury, bliskich, tych, na których nam zależało, ludzi, którzy wyrządzili nam krzywdę, i ludzi, których my skrzywdziliśmy, uczynków (dobrych i złych) wobec siebie i innych, doświadczeń i podjętych decyzji, aby stworzyć to, kim jesteśmy obecnie ${ }^{15}$.

James E. Marcia jest psychologiem klinicznym i rozwojowym odpowiedzialnym za przedstawienie 4 typów statusu tożsamości. Marcia opracował wywiad tożsamościowy, metodę częściowo ustrukturyzowanego wywiadu do badań tożsamości psychologicznej, która skupia się na zakresie eksploracji i zaangażowania poszczególnych osób w różne obszary życia danej jednostki. Na tej podstawie wyszczególnił: przejęcie tożsamości, tożsamość lustrzaną, tożsamość moratoryjną oraz tożsamość dojrzałą ${ }^{16}$.

Pierwszym z wymienionych rodzajów jest przejęcie tożsamości. Ma ono miejsce wtedy, gdy zobowiązania są podejmowane bez poszukiwania alternatyw. Często są one oparte na ideach i przekonaniach rodziców ${ }^{17}$. Jednostki mogą wykluczać przekazaną tożsamość dobrowolnie lub pod

14 Por. G. Kirk, M. Okazawa-Rey, Identities and Social Locations: Who am I? Who are My People?, http://www.drvalverde.com/uploads/1/o/5/3/10538520/who_am_i__who_are_ my_people_-_kirk_and_okazawa.pdf (30.12.2019).

15 Por. P.J. Palmer, The heart of a teacher: Identity and integrity in teaching, https://web.archive.org/web/20120105062059/http://www.mcli.dist.maricopa.edu/events/afc99/articles/ heartof.pdf (30.12.2019). 
presją. Przypadek „negatywnej tożsamości” ma miejsce, gdy młodzież przyjmuje tożsamość w opozycji do przypisanej tożsamości. Należy pamiętać, że po wystąpieniu kryzysu tożsamości powrót do statusu wykluczenia nie jest już możliwy ${ }^{18}$.

Kolejnym typem jest tożsamość lustrzana. Młodzież niezdolna stawić czoła konieczności rozwoju tożsamości w wyniki wielu czynników, w tym również braku odpowiedniego wzoru ojca i jego obecności w życiu, unika eksploracji lub podejmowania zobowiązań, pozostając w stanie, który może powodować izolację społeczną ${ }^{19}$. Rozproszenie tożsamości jest charakterystyczne dla tych, którzy nie badali ani nie podejmowali zobowiązań w obszarach definiujących życie. Być może doświadczyli również kryzysu tożsamości ${ }^{20}$.

Tożsamość moratoryjna charakterystyczna jest dla osób będących w trakcie kryzysu, których zobowiązania są niejasno określone ${ }^{21}$. Tendencja polega na tym, że znaczna grupa jednostek zatrzymuje się na moratorium, co może być traktowane jako tymczasowa dorosłość ${ }^{22}$.

Po doświadczeniu kryzysu i zażegnaniu go prawdopodobnym postępem będzie przejście od dyfuzji przez moratorium do osiągnięcia tożsamości. Tożsamość dojrzała jest zatem statusem jednostek, które zazwyczaj przeżyły kryzys, przeszły badania tożsamości i podjęły świadome i konkretne zobowiązania ${ }^{23}$.

\section{Rola ojca w procesie kształtowania tożsamości}

Niezwykle istotną w życiu młodego człowieka jest rodzina, bez względu na to, czy są to rodziny biologiczne, rozszerzone czy adopcyjne. Każda z nich ma zasadniczy wpływ na rozwój tożsamości dziecka poprzez interakcję między jej członkami a młodą, dorastającą osobą ${ }^{24}$. Badacze i teoretycy za-

18 Por. J.E. Marcia, Ego-Identity Status..., dz. cyt., s. 118-133.

19 Por. M. Gawinecka, M. Radko, I. Łucka, Sport jako aktywny styl życia - w poszukiwaniu wtasnej tożsamości, „Psychologia” tom 7, nr 3, s. 117-122.

20 Por. J.E. Marcia, Ego-Identity Status..., dz. cyt., s. 118-133.

21 Por. M. Gawinecka, M. Radko, I. Łucka, Sportjako aktywny styl życia..., dz. cyt., s. 117-122.

22 Por. G. Sheehy, New Passages: Mapping Your Time Across Time, Nowy Jork 1996, s. 10, 43.

23 Por. J.E. Marcia, Ego-Identity Status..., dz. cyt., s. 118-133.

24 Por. H.D. Grotevant, Family processes, identity development, and behavioral outcomes for 
sadniczo stwierdzają, że na tożsamość jednostki, a szczególnie nastolatka, mają wpływ ludzie dla nich najbliżsi, w szczególności ojciec i matka oraz środowisko, w którym dorastają i żyją ${ }^{25}$. Oddziaływanie to może oczywiście być nacechowane tak pozytywnie, jak i negatywnie - w zależności od dojrzałości otoczenia ${ }^{26}$. Dotyczy to obu płci i ukazuje fundamentalną rolę rodziny w procesie kształtowania się tożsamości dziecka.

Rodzaj relacji z rodzicami odgrywa znaczącą rolę w kształtowaniu tożsamości człowieka. Gdy istnieje silny i pozytywnie nacechowany związek między rodzicem a nastolatkiem, znacznie bardziej prawdopodobne jest, że dorastający człowiek poczuje swobodę w badaniu tożsamości, którą chce wykreować dla siebie. Zarówno u chłopców, jak i dziewcząt na kształtowanie tożsamości pozytywnie wpływa zaangażowanie rodziców, szczególnie w obszarach wsparcia, monitorowania społecznego i monitorowania w szkole ${ }^{27}$.

Niewątpliwie więź dziecka z ojcem jest relacją szczególną i nacechowaną wieloma niezwykle istotnymi aspektami. Zanim jednak uwaga skupiona zostanie na roli ojca w procesie kształtowania tożsamości, warto zadać sobie pytanie, kogo określamy tym terminem.

Przez lata rola ojca w życiu dziecka sprowadzana była głównie do zapewnienia zaplecza finansowego czy dostarczenia innych dóbr, które stanowiły niezbędne elementy codziennego funkcjonowania rodziny. Niejednokrotnie ojciec figurował również jako stróż dyscypliny i domowego miru. Inne wymiary i aspekty ojcostwa zostawały pomijane i bagatelizowane. Reflektory uwagi kierowane były na matki, a ich miłość i wszelkie przymioty uznawano za kluczowe czynniki rozwoju dziecka oraz kształtowania się jego tożsamości ${ }^{28}$.

adopted adolescents, „Journal of Adolescent Research”, nr 12 (1), s. 139-161.

25 Por. L. Steinberg, Adolescence Development, „Annual Review of Psychology”, nr 25 (1), s. $83-110$.

26 Por. E. W. Willemsen, K. K. Waterman, Ego Identity Status and Family Environment: A Correlational Study, „Psychological Reports”, nr 69 (3), s. 1203-1212.

27 Por. C.E. Sartor, J. Youniss, The relationship between positive parental involvement and identity achievement during adolescence, „Adolescence”, nr 37, s. 221-234.

28 Por. M. Target, P. Fonagy, Ojcowie we wspótczesnej psychoanalizie i w społeczeństwie. Rola ojca w rozwoju dziecka, w: Po co sa ojcowie. Rozważania psychoanalityczne, red. J. Trowell, A. Etchegoyen, Gdańsk 2015, s. 58. 
Coraz częściej jednak to ojciec znajduje się w centrum zainteresowania badaczy. Aktualnie obserwujemy dużo większą świadomość oraz zaangażowanie wśród ojców, a temat ojcostwa nie stanowi żadnego novum. Choć część mężczyzn - a także kobiet - wciąż żyje wizjami przeszłości, redukując rolę ojca do cech wymienionych w poprzednim akapicie, niebagatelna rola ojcostwa - niegdyś nierozpoznawalna - jest dziś doceniana, a szeroko pojęta tematyka „tacierzyństwa” poruszana jest znacznie częściej²9.

Kim zatem jest ojciec? Formalnie, na kanwie prawa rodzinnego obowiązującego w Polsce, ojciec jest wstępnym krewnym pierwszego stopnia w linii prostej, od którego dziecko pochodzi bezpośrednio ${ }^{30}$. Jednak z uwagi na złożoność i dynamikę zmian zachodzących w dzisiejszej rodzinie nie możemy zapominać także o powinowactwie, wynikającym z relacji mężczyzny z biologiczną matką dziecka, niejednokrotnie skutkującym aktywnym i żywym uczestnictwem w życiu chłopca czy dziewczynki. Coraz bardziej popularne stają się bowiem rodziny zrekonstruowane ${ }^{31}$, w których rolę ojca małego dziecka przejmuje nowy partner matki ${ }^{32}$.

Pomimo, iż rola ojca niewątpliwie ma charakter pierwotnie biologiczny, wpisany jest w nią - co znacznie bardziej istotne - aspekt społeczny i psychologiczny. Dlatego słuszną definicją wydaje się być ta sformułowana przez prof. Marię Braun-Gałkowską: „Być ojcem to od początku umieszczać dziecko w kontekście społecznym [...], to umożliwić dziecku określenie swojej płci i roli w życiu [...]. Być ojcem więc, to może stawiać wymagania, podprowadzać pod zadania coraz trudniejsze, ale jednocześnie umożliwiać ich realizację przez stałą życzliwą bliskość”33. Takie ujęcie terminu „ojciec” wskazuje na role, jakie mężczyzna posiadający dziecko winien pełnić w jego życiu.

Należałoby rozdzielić również terminy „ojciec” oraz „ojcostwo”. Nie jest to jednak tematem niniejszego artykułu. Aczkolwek - choć jest to kwestia

29 M. Target, P. Fonagy, Ojcowie we wspótczesnejpsychoanalizie..., dz. cyt., s. 58.

30 Por. Anna Kurtyna, Wstępni $i$ zstępni, https://www.infor.pl/prawo/dziecko-i-prawo/ slownik/89418,Wstepni-i-zstepni.html (24.11.2020).

31 Por. Pew Research Center, The American family today, https://www.pewsocialtrends. org/2015/12/17/1-the-american-family-today/ (24.11.2020).

32 Por. gus, Sytuacja demograficzna Polski do 2018 roku. Tworzenie i rozpad rodzin, https:// stat.gov.pl/obszary-tematyczne/ludnosc/ludnosc/sytuacja-demograficzna-polski-do-2018-roku-tworzenie-i-rozpad-rodzin,33,2.html (24.11.2020).

33 M. Braun-Gałkowska, Psychologia domowa, Kraków 2018. 
dużo bardziej złożona - zwróćmy uwagę na to, iż termin „ojciec” wskazuje na pewien stan, przyjętą rolę, fakt bycia. Ojcostwo natomiast odzwierciedla szereg czynności podejmowanych przez mężczyznę - ojca. Są to m.in.: zapewnienie warunków materialnych, podejmowanie działań opiekuńczych, wychowawczych czy przygotowanie dziecka do uczestnictwa w kulturze ${ }^{34}$.

Niezaprzeczalnie ojciec pełni w rozwoju dziecka symptomatyczną, niezwykle ważną, a także trudną rolę. Twórca psychoanalizy Sigmund Freud twierdził, iż najistotniejszą rolę w procesie kształtowania osobowości dziecka odgrywa właśnie on - ojciec. Wskazywał, iż jest on kluczowym elementem kształtowania mechanizmów funkcjonowania tzw. „ja idealnego” (tj. „superego”), czyli - w dużym uproszczeniu - sfery moralnej człowieka.

Jak podkreśla psychoterapeutka Marta Mauer-Włodarczyk, to właśnie wzór ojca daje chłopcom „fundament męskiej tożsamości”35. Podświadomie przejęte wzorce, obserwacja ojca, chęć powielania jego zachowań tych pozytywnych, zwłaszcza tych odbieranych jako bohaterskie - procentuje przez lata życia. Autorka podkreśla, iż „tylko ojciec może pokazać dziecku, że świata i życia nie warto się bać. Tylko ojciec potrafi przekazać dziecku ten niesamowity spokój i odwagę"36.

Relacja ojciec-dziecko już od pierwszych chwil życia potomka umożliwia przełamanie diady dziecka $\mathrm{z}$ matką ${ }^{37}$. Wzmacnia to autonomię, indywidualizację oraz niezależność dziecka już na początku jego życia, skutkując lepszym przystosowaniem psychicznym córek i synów oraz zwiększeniu elastyczności ich funkcjonowania ${ }^{38}$. Wpływa to także bezpośrednio na radzenie sobie z osobowościowymi i psychologicznymi problemami u dzieci, następnie nastolatków i młodych dorosłych. Relacja z ojcem jest także filarem, na którym dziecko opiera obraz samego siebie, poczucie wartości, stabilność emocjonalną, a nawet poziom agresji, czyli elementy niezbędne do ukształtowania się tożsamości dojrzałej ${ }^{39}$.

34 Por. T. Sosnowiecki, Pedagogiczny model ojcostwa - konstrukt teoretyczny, „Dziecko krzywdzone. Teoria, badania, praktyka”, 13 (3), s. 56-73.

M. Mauer-Włodarczyk, Rola ojca - budowanie odwagi i męskiej tożsamości, https://www. psychologiakobiety.pl/rola-ojca-budowanie-odwagi-i-meskiej-tozsamosci/ (24.11.2020).

M. Mauer-Włodarczyk, Rola ojca - budowanie odwagi i męskiej tożsamości..., dz. cyt.

37 Por. D. Wernio, Wspótczesne Ojcostwo - „Tacierzyństwo”, https://edurada.pl/artykuly/ wspolczesne-ojcostwo-tacierzynstwo/ (24.11.2020).

38 D. Wernio, Wspótczesne Ojcostwo - „Tacierzyństwo”..., dz. cyt.

39 D. Wernio, Wspótczesne Ojcostwo - „Tacierzyństwo”..., dz. cyt. 
Aktywny w życiu dziecka ojciec wpływa na wzrost inteligencji dziecka, pewność siebie oraz tożsamość płciową. Ponadto ojcowie stanowią kluczowy element w procesie socjalizacji swoich dzieci ${ }^{40}$. Relacja z ojcem rzutuje na wczesny rozwój emocjonalności u dziecka, ekspresję i regulację emocji oraz emocjonalne zrozumienie. Typowi ojcowie - znani z organizowania bardziej szalonych i mniej przewidywalnych atrakcji niż matki wprowadzają do życia dziecka spontaniczne, pozytywne emocje, których te nie byłyby w stanie odkryć, uczestnicząc jedynie w konwencjonalnych zabawach oferowanych przez mamy ${ }^{41}$.

Kluczowym elementem, który wpływa pozytywnie na kształtowanie tożsamości dziecka w relacji z ojcem, jest obecność taty w procesie dorastania $^{42}$. Tak budowanie tożsamości, jak również samo ojcostwo to dyscypliny długodystansowe. Aby oba te procesy przebiegały pomyślnie, a ich efektem było wychowanie jednostki silnej i wartościowej, o stabilnym poczuciu własnej tożsamości, kompetencje pedagogiczne ojca wcale nie są najbardziej istotne. Oczywiście ojciec, który jest dobrym wychowawcą, stanowi nieoceniony walor, jednak to aktywna, pełna otwartości i wrażliwości obecność w życiu dziecka jest w procesie indywiduacji składnikiem elementarnym ${ }^{43}$.

Nie sposób zatem nie zgodzić się również ze zdaniem szwajcarskim teologa Hansa Ursa von Balthasara: "Ja może powstać i istnieć tylko w miłującym je Ty”. Bez obu czynników występujących łącznie, a zatem obecności i miłości, nie jesteśmy w stanie prawidłowo wykształcić ,ja” człowieka, czyli jego tożsamości. Stwierdzenie to znajduje szczególne odzwierciedlenie właśnie w relacji ojciec-dziecko. Poprzez swoiste spotkanie, bliską relację dziecka $z$ najbliższymi, realizowany może być najpełniej proces wychowania, a co za tym idzie - budowania własnej tożsamości ${ }^{44}$. Chodzi tutaj o prawdziwą więź, coś więcej niż tylko świadomość, że ojciec jest obok. Niezwykle trafnie sens spotkania oddają słowa Genowefy Koć-Seniuch: „Spotkać, to wykraczać poza siebie, to doświadczać Innego”45. To

40 D. Wernio, Współczesne Ojcostwo - „Tacierzyństwo”..., dz. cyt.

41 D. Wernio, Wspótczesne Ojcostwo - „Tacierzyństwo”..., dz. cyt.

42 Por. D. Wernio, Tato, twoja obecność jest potrzebna, https://zmianywzyciu.pl/tato-twoja-obecnosc-jest-potrzebna-26o/ (24.11.2020).

43 D. Wernio, Tato, twoja obecność jest potrzebna..., dz. cyt.

44 Por. T. Sosnowiecki, Pedagogiczny model ojcostwa..., dz. cyt., s. 56-73.

45 G. Koć-Seniuch, G., Dialog, w: Encyklopediapedagogiczna XXI wieku, t. 2, Warszawa 2003, s. 690 . 
właśnie tak definiowanie spotkania obrazuje sens procesu wychowawczego, procesu stawania się przez relacje człowieka z drugim człowiekiem ojca $\mathrm{z}$ dzieckiem ${ }^{46}$.

Młode jednostki, które pozbawione są takiego spotkania - kontaktu z ojcem - mogą doświadczać poczucia osamotnienia, ponieważ w ich życiu nie ma męskiego wzorca. Prowadzić to może do problemów z kształtowaniem się tożsamości, ponieważ nawet najlepsza matka nigdy nie jest w stanie w pełni wynagrodzić swoim dzieciom braku ojca. Rozwój dzieci, których ojcowie z różnych przyczyn nie uczestniczyli w ich życiu, zostaje zaburzony w wielu sferach, m.in. w sferze intelektualnej, emocjonalnej, moralnej czy religijnej. Płeć dziecka nie ma znaczenia - zaburzenia rozwoju mogą pojawić się zarówno u synów, jak i u córek ${ }^{47}$.

Jeśli chłopiec nie ma kontaktu ze swoim ojcem, dojrzewa on bez wzorca męskiego, który jest niezbędny do rozwoju psychoseksualnego. Dzieci, które od najmłodszych lat doświadczają aktywnej obecności ojca w swoim życiu, zdecydowanie lepiej radzą sobie z nawiązywaniem kontaktów międzyludzkich niż jednostki, które takiego kontaktu nie doświadczyły. W związku z tym osoby pozbawione relacji z tatą często nie są odpowiednio przygotowane do funkcjonowania w społeczeństwie. Dziecko już od trzeciego roku życia odczuwa potrzebę przebywania z ojcem, co ściśle związane jest z procesem identyfikacji i utożsamiania się z konkretną płcią. W tym okresie relacja ojca $z$ synem jest niezwykle istotna, ponieważ ułatwia dziecku postrzeganie siebie jako jednostki należącej do płci męskiej ${ }^{48}$. Kilka lat później syn zaczyna naśladować ojca, co skutkuje reorientacją zachowań, które są konieczne, aby stać się mężczyzną ${ }^{49}$. Niewłaściwe relacje z rodzicami, niedostatek miłości czy akceptacji, często doprowadzają do sytuacji, w której dorosły mężczyzna nie jest w stanie nawiązywać trwałych i solidnych relacji z innymi osobami, zwłaszcza z kobietami ${ }^{50}$. Co więcej, chłopcy, którzy uważali swojego ojca za opie-

46 Por. T. Sosnowiecki, Pedagogiczny model ojcostwa..., dz. cyt., s. 56-73.

47 Por. I. Šipowa, Wptyw sytuacji matżeńskiej rodziców, zwłaszcza postaw ojcowskich, na rozwój osobowości synów, „Problemy Rodziny”, nr 6, s. 39-42.

48 Por. L. M. Youngblade, J. Belsky, Parent-child antecedents of 5-year-olds' close friendships: A longitudinal analysis, „Developmental Psychology”, nr 28, s. 700-713.

49 Por. H. B. Biller, Father, Child and Sex Role: Paternal Determinants of Personality Development, „American Anthropologist”, s. 1367-1368.

50 Por. K. Pospiszyl, Ojciec a wychowanie dziecka, Warszawa 2007, s. 46-57. 
kuńczego i ciepłego, okazują znacznie więcej życzliwości i zrozumienia w stosunku do innych niż ci, którzy nie posiadali w dzieciństwie wzorca męskiego ${ }^{51}$. Pewność siebie, asertywność, a także kompetencje społeczne ściśle związane są z relacją ojca i syna ${ }^{52}$. Jeżeli ojciec wykazuje negatywne uczucia w stosunku do swojego syna, dziecko w przyszłości może mieć problemy z efektywnym i odpowiednim działaniem podczas interakcji z innymi jednostkami, a także może być nieśmiałe, agresywne, wycofane a nawet przejawiać zachowania destrukcyjne ${ }^{53}$. Ponadto, powstawanie wielu zaburzeń seksualnych przypisuje się właśnie nieobecności ojca w życiu dziecka. Należy również pamiętać, że wiele z takich nieprawidłowości nie jest możliwych do wyleczenia. Tożsamość seksualna ściśle związana jest z rolą ojca w życiu syna i jej kształtowanie jest jednym z najważniejszych zadań, którym sprostać musi ojciec. Chłopiec, naśladując swojego ojca i upodabniając się do niego, umacnia w sobie obraz mężczyzny ${ }^{54}$. Badania wskazują, że aktywna rola taty w życiu syna musi być powiązana z czułością i opiekuńczością. Pomaga to w wykształceniu się w młodym człowieku pożądanych cech męskich, które posiada jego ojciec ${ }^{55}$.

W przypadku kształtowania się tożsamości dziewcząt ojciec również pełni rolę kluczową. Proces rozwoju psychospołecznego dziecka i wykształcenia się jego tożsamości, zwłaszcza w przypadku dziewczynki, nie może prawidłowo odbywać się z tylko z udziałem matki. Rola ojca jest tutaj także niezwykle ważna. Wynika to potrzeby kontaktu tak z matką, jak i ojcem, która towarzyszy dziecku już od początku jego życia ${ }^{56}$. Tata wpływa na jej poglądy, postawy, a także na kształtowanie się jej osobowości oraz tożsamości. Konsekwentna i aktywna obecność ojca w życiu dziewczynki, wrażliwość na jej uczucia, wysłuchanie oraz zainteresowanie jej pasjami pomagają zmniejszyć niepewność najpierw młodej, następ-

51 Por. R. D. Parke, J. Dennis.Mary L. Flyr, K. L. Morris, C. Killian, David J. McDowell, M. Wild, Fathering and Children's Peer Relationship, w: The Role of the Father in Child Development, Hoboken 2004, s. 307-340.

52 Por. M. L. Hoffman, Identification and Conscience Development, „Child Development”, nr 42, s. 1071-1081.

53 Por. P.A. Foster, M. Reese-Weber, J.H. Kahn, Fathers' Parenting Hassles ad Coping: Associations with Emotional Expressiveness and their Sons' Socioemotional Competence, „Infant and Child Development", nr 16, s. 277-293.

54 Por. H. B. Biller, Father, Child and Sex Role..., dz. cyt., s. 1367-1368.

55 Por. R.B.Ginsberg, Parent-Adolescent Relationship Program..., dz. cyt., s. 108-112.

56 Por. H. Bee, D. Boyd, Life span development, Boston 2003, s. 125-126. 
nie dorosłej kobiety oraz powodują wzrost zaufania do siebie samej, innych oraz własnych umiejętności. Badania przeprowadzone przez Mieczysława Plopę wykazały, że w przypadku kształtowania się sfery emocjonalnej u córek rola ojca jest bardziej istotna niż u synów ${ }^{57}$. To on wpływa na sprecyzowanie przez dziewczynkę późniejszych celów życiowych, a także na przyswajanie przez nią konkretnych wartości, które są trzonem i elementarną składową budowania jej tożsamości i światopoglądu ${ }^{58}$.

Relacja ojca i córki stanowi punkt odniesienia dla relacji damsko-męskich, w które kobieta będzie w przyszłości wchodziła. To właśnie ojciec jest pierwszym mężczyzną w życiu kobiety i do pewnego momentu jej rozwoju jest on tym najważniejszym. Jest swoistym wzorem dla córki, stanowiącym o tym, w jaki sposób powinna ona być kochana oraz traktowana przez mężczyzn w przyszłości. To od niego zależy, czy córka będzie pewna siebie, samodzielna i świadoma swojej wartości, czy też nie. Ojciec może stać się dla córki wzorem idealnego mężczyzny lub być jego przeciwieństwem. W przypadku braku relacji ojca i córki u dziewcząt mogą pojawić się problemy w sferze nie tylko wewnętrznej (np. problemy emocjonalne czy związane z brakiem poczucia własnej wartości), ale także w sferze relacyjnej (np. podczas kontaktów z mężczyznami). W przypadku dziewcząt brak ojca (brak fizyczny lub/i uczuciowy) może pogłębiać chęć bliskości i miłości. W przyszłości istnieje szansa, że kobieta będzie zabiegała o mężczyzn, chcąc uzupełnić pustkę, która powstała na skutek nieobecności ojca Ponadto, może ona odczuwać, że na miłość i szacunek ze strony drugiej osoby trzeba zasłużyćc ${ }^{59}$.

\section{Zakończenie}

Tożsamość stanowi niezwykle istotny element życia każdego człowieka. To dzięki niej jednostka może stworzyć spójny obraz samej siebie. Tok kreowania tożsamości jest zazwyczaj procesem bardzo skomplikowanym,

57 Por. M. Plopa, Psychologia rodziny: teoria i badania, Kraków 2005, s. 252.

58 Por. D. Krok, K. Rychtarczyk, Wptyw relacji z ojcem na percepcję wizerunku ciała u kobiet w wieku późnej adolescencji, Opole 2010, s. 232.

59 Por. Małgorzata Kwiecińska, Relacja córkiz ojcem-jakwpływa na życie?, https://pl.aleteia. org/2017/o6/23/relacja-corki-z-ojcem-jak-wplywa-na-zycie/ (31.12.2019). 
ponieważ wpływa na niego wiele czynników zewnętrznych, i w większości przypadków trwa on całe życie.

Istotnym elementem w budowaniu tożsamości jednostki są rodzice, w szczególności ojciec, który odgrywa kluczową rolę w tej materii. To właśnie jego postawa silnie związana jest z kształtowaniem się obrazu własnego „ja” dziecka. Ojciec staje się dla syna wzorem i drogowskazem na drodze do osiągnięcia dojrzałości. Nadaje mu on konkretną tożsamość, sposób myślenia o sobie, a także system wartości i kręgosłup moralny, który ten zabiera w dorosłość. Córka natomiast dzięki pełnej miłości i akceptacji więzi z ojcem ma szansę na obiektywną i pozbawioną kompleksów autopercepcję. Afirmowana i rozumiana przez ojca od dzieciństwa, a także otoczona konstruktywną i z miłości wypływającą krytyką, wkracza w życie, posiadając zdrowy obraz siebie oraz poczucie wartości.

Dla chłopców ojciec jest obiektem identyfikacji, natomiast dziewczynkom prawidłowa relacja $\mathrm{z}$ tatą pozwala na określenie swojej kobiecości. Uczestnictwo ojca w procesie wychowania dziecka - niezależnie od płci - skutkuje zbudowaniem zdrowego poczucia wartości oraz konstruktywizmem w ocenie rzeczywistości i zachodzących w niej procesów. Są to jedynie nieliczne spośród pozytywnych skutków aktywnej obecności ojca w toku budowania tożsamości dziecka, wskazujących na jego fundamentalną rolę w tym procesie.

\section{Abstrakt}

\section{Relacja z ojcem jako filar ksztattowania tȯ̇samości dziecka}

Przedmiotem niniejszego artykułu jest rola ojca w kształtowaniu się tożsamości dziecka. W pierwszej części przedstawiono najistotniejsze informacje dotyczące kwestii tożsamości i zależności wpływających na jej formowanie oraz przybliżono znaczące stanowiska psychologów oraz socjologów specjalizujących się w tej dziedzinie. W drugiej części pracy zaprezentowano opis i analizę roli ojca w toku kształtowania się tożsamości jednostki, jego kluczową funkcję w tym aspekcie, jak i wpływ jego braku na przebieg procesu indywiduacji córek i synów. 
Słowa kluczowe: Tożsamość, tożsamość indywidualna, tożsamość dziecka, ojciec, relacja z ojcem

\section{Abstract}

The relationship with father as the core of shaping child's identity

The main goal of this article is to point the influence of the father in building the child's identity. The first part of the work focuses on the identity itself and dependencies which influence its formation. Important positions of psychologists and sociologists interested in this area are included. The next part of following paper is dedicated to key role of father in shaping the identity of each child, as well as the impact of his absence on the course of the child's individuation process. Aspects concerning both girls and boys issues are included.

Keywords: Identity, individual identity, child identity, father, dad-child relationship.

\section{Bibliografia}

Biller H. B., Father, Child and Sex Role: Paternal Determinants of Personality Development, „American Anthropologist” (1971), s. 1367-1368.

Borutka T., Kornecki T., Kroczek P., Rodzina fundamentem społeczeństwa. Aspekt społeczno-prawny, Wydawnictwo Naukowe, Kraków 2017.

Braun-Gałkowska M., Psychologia domowa, Wydawnictwo Akademickie Żak, Kraków 2018.

Foster P.A., Reese-Weber M., Kahn J.H., Fathers' Parenting Hassles ad Coping: Associations with Emotional Expressiveness and their Sons' Socioemotional Competence, „Infant and Child Development” 16 (2007), 277-293.

Gawinecka M., Radko M., Łucka I., Sport jako aktywny styl życia - w poszukiwaniu wtasnej tożsamości, „Psychologia” 7 (2010), nr 3, s. 117-122. 
Ginsberg B. G., Parent-Adolescent Relationship Program (PARD): Relationship enhancement therapy with adolescents and their families (fathers and sons), „Psychotherapy” 35 (1995)1, s. 108-112.

Goltz H.H., Smith M.L., Forming and Developing Your Professional Identity Easy as PI, „Health Promotion Practice” (2020) 15 (6), s. 785-789, DOI: $10.1177 / 1524839914541279$.

Grotevant H.D., Family processes, identity development, and behavioral outcomes for adopted adolescents, "Journal of Adolescent Research” (1997) nr 12 (1), s. 139-161, https://doi.org/10.1177/0743554897121008.

GUs, Sytuacja demograficzna Polski do 2018 roku. Tworzenie i rozpad rodzin, https://stat.gov.pl/obszary-tematyczne/ludnosc/ludnosc/sytuacja-demograficzna-polski-do-2018-roku-tworzenie-i-rozpad-rodzin,33,2.html (24.11.2020).

Hoffman L.M., Identyfication and Conscience Development, „Child Development”, nr 42, s. 1071-1081. James P. I., Despite the Terrors of Typologies: The Importance of Understanding Categories of Difference and Identity, „Interventions: International Journal of Postcolonial Studies"(2019) nr 17 (2), s. $174-195$.

Kirk G., Okazawa-Rey M., Identities and Social Locations: Who am I? Who are My People?, http://www.drvalverde.com/uploads/1/o/5/3/10538520/who_ am_i__who_are_my_people_-_kirk_and_okazawa.pdf (30.12.2019).

Koć-Seniuch G., Dialog, w: Encyklopedia pedagogiczna XXI wieku, t. 2, red. T. Pilch, Pwn, Warszawa 2003, s. 690.

Konwencja o Prawach Dziecka. Dz.U. z 1991 r. nr 120, poz. 526.

Krampe E. M., Newton R. R., The Father Presence Questionnaire: A New Measure of the Subjective Experience of Being Fathered. Fathering, 4, 2, http:// citeseerx.ist.psu.edu/viewdoc/download?doi=10.1.1.839.9976\&rep=rep1\& type $=\operatorname{pdf}(30.12 .2019)$, s. 159-190.

Kurtyna A., Wstępni izstępni, https://www.infor.pl/prawo/dziecko-i-prawo/ slownik/89418,Wstepni-i-zstepni.html (24.11.2020).

Kwiecińska M., Relacja córki z ojcem - jak wptywa na życie?, https://pl.aleteia. org/2017/o6/23/relacja-corki-z-ojcem-jak-wplywa-na-zycie/ (30.12.2019).

Leary M.R., Tangney J. P., Handbook of self and identity, Nowy Jork, Londyn 2003.

Marcia J.E., Ego-Identity Status, „Journal of Personality” (1966) nr 35 (1), s. $118-133$. 
Mauer-Włodarczyk M., Rola ojca - budowanie odwagi i męskiej tożsamości, https://www.psychologiakobiety.pl/rola-ojca-budowanie-odwagi-i-meskiej-tozsamosci/ (23.11.2020).

Palmer P. J., The heart of a teacher: Identity and integrity in teaching, 5.01.2012, https://web.archive.org/web/20120105062059/http://www.mcli.dist.maricopa.edu/events/afc99/articles/heartof.pdf (30.12.2019).

Parke D.R., Dennis J., Flyr M.L., Morris K.L., Killian C., McDowell D.J., Wild M., Fathering and Children's Peer Relationship, w: The Role of the Father in Child Development, eds. M.E. Lamb, Hoboken 2004, s. 307-340. Pew Research Center, The American family today, https://www.pewsocialtrends.org/2015/12/17/1-the-american-family-today/ (24.11.2020).

Pospiszyl K., Ojciec a wychowanie dziecka, Warszawa 2007.

Sartor C. E., Youniss J., The relationship between positive parental involvement and identity achievement during adolescence, ,Adolescence” (2002) nr 37, s. 221-234.

Sheehy G., New Passages: Mapping Your Time Across Time, Nowy Jork 1996. Šipowa I., Wptyw sytuacji matżenskiej rodziców, zwłaszcza postaw ojcowskich, na rozwój osobowości synów, „Problemy Rodziny” (1984) nr 6, s. 39-42.

Steinberg L., Adolescence Development, "Annual Review of Psychology” (2001) nr 25 (1), s. 83-110.

Węgrzyn G., Tożsamość Ekonomiczna Górnoślązaków, Katowice 2017, s. 8-10. Weinreich P., Sanderson W., Analysing Identity: Cross-Cultural, Societal and Clinical Contexts, East Sussex 2003, s. 8, 26-34.

Weinreich P., The operationalisation of identity theory in racial and ethnic relations, „Theories of Race and Ethnic Relations. Comparative Ethnic and Race Relations" (2011), s. 299.

Wernio D., Tato, twoja obecnośćjest potrzebna, https://zmianywzyciu.pl/tato-twoja-obecnosc-jest-potrzebna-26o/ (24.11.2020).

Wernio D., Wspótczesne Ojcostwo - „Tacierzyństwo”, https://edurada.pl/artykuly/wspolczesne-ojcostwo-tacierzynstwo/ (24.11.2020).

Willemsen E.W., Waterman, K K., Ego Identity Status and Family Environment: A Correlational Study, „Psychological Reports”, nr 69 (3_suppl), s. 1203-1212, https://doi.org/10.2466/pro.1991.69.3f.1203.

Youngblade L. M., Belsky, J., Parent-child antecedents of 5-year-olds' close friendships: A longitudinal analysis, „Developmental Psychology” (1992) nr 28, s. 700-713. 